\title{
БИОЛОГИЧЕСКАЯ БЕЗОПАСНОСТЬ ФАРША НА ОСНОВЕ МЯСА ПЕРЕПЕЛА, ОБОГАЩЕННОГО БЕЛКОВО-УГЛЕВОДНОЙ КОМПОЗИЦИЕЙ И ФЕРМЕНТОМ ТРАНСГЛЮТАМИНАЗОЙ
}

\author{
E.A. Gartovannaya, K.S. Ivanova
}

\section{BIOLOGICAL SAFETY OF MINCED MEAT ON THE BASIS OF QUAIL MEAT ENRICHED WITH PRO- TEIN-CARBOHYDRATE COMPOSITION AND TRANSGLUTAMINASE ENZYME}

Гартованная Елена Александровна - канд. техн. наук, доц. каф. технологии переработки продукции растениеводства Дальневосточного государственного аграрного университета, г. Благовещенск. E-mail: lena1973blag@mail.ru

Иванова Клавдия Сергеевна - асп. каф. технологии переработки продукции животноводства Дальневосточного государственного аграрного университета, г. Благовещенск.

E-mail: klava82iva@mail.ru

Цель исследования - определить безопасность фрарша на основе мяса перепела, обогащенного белково-углеводной композищией и ферментом трансглютаминазой. Задачи исследования - провести экспериментальное скармливание и исследовать на безопасность фраршевый продукт на основе мяса перепела, обогащенного белково-углеводной композицией и ферментом трансглютаминазой; определить влияние его на организм лабораторных животных, дать описание биохимических, общих клинических показателей крови и патологических изменений в органах белых лабораторных крыс. Исследование проводилось на базе технологического факультета и фракультета ветеринарной медицины и зоотехнии Дальневосточного государственного аграрного университета города Благовещенска Амурской области. Мясорастительный продукт, разработанный из фраршевой композиции, скармливали на протяжении 35 дней бельм лабораторным крысам. Для эксперимента и проводимых аналогичных работ были сформированы три подопытных группы крыс со средней живой массой тела 221,5 $20,87-$

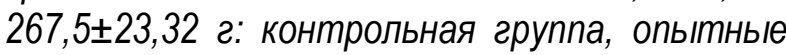

Gartovannaya Elena Alexandrovna - Cand. Techn. Sci., Assoc. Prof., Chair of Technology of Plant Growing Production Processing, Far Eastern State Agrarian University, Blagoveshchensk.

E-mail: lena1973blag@mail.ru

Ivanova Klavdiya Sergeevna - Post-Graduate Student, Chair of Technology of Animal Husbandry Production Processing, Far Eastern State Agrarian University, Blagoveshchensk.

E-mail: klava82iva@mail.ru

группы 1 и 2. В ходе исследования был произведен забор крови у крыс контрольной и опытных групn для проведения работы по определению показателей общего клинического анализа и биохимического состава. Все показатели оставались в пределах допустимых норм, и нормативные значения количества лейкоцитов способствовали увеличению скорости привесов опытных животных и росту цветового показателя в рамках фризиологических значений, что могло свидетельствовать о лучшем насыщении эритроцитов гемоглобином. При проведении патолого-анатомического вскрытия негативного влияния вводимой в продукт мясорастительной композиции на внутренние органы лабораторных животных не выявлено. Bce это говорит о безопасности фрарша на основе мяса перепела, обогащенного белковоуглеводной композицией и ферментом трансглютаминазой. Применение предложенной фраршевой композиции поможет расширить мясорастительный ассортимент.

Ключевые слова: фрарш, белковоуглеводная композиция, лабораторные животные, клинический анализ крови, биологическая безопасность. 
The research objective was to define the safety of minced meat on the basis of the meat of quail enriched with proteinaceous and carbohydrate composition and enzyme transglutaminase. The research problems were to carry out experimental feeding and to investigate the safety of minced meat product on the basis of the meat of quail enriched with proteinaceous and carbohydrate composition and enzyme of the transglutaminase; to define the influence of it on the organisms of laboratory animals, to give the description of biochemical, general clinical indicators of blood and pathological changes in the bodies of white laboratory rats. The research was conducted on the basis of the Faculty of Technology and the Faculty of Veterinary Medicine and Zootechnics of the Far Eastern State Agrarian University of Blagoveshchensk, Amur Region. The meat and cereal product developed from minced meat composition was fed for 35 days to white laboratory rats. For the experiment and carried-out similar works three experimental groups of rats with average live body weight 221.5 $\pm 20.87-267.5 \pm 23.32$ were created: control group, experimental groups 1 and 2. During the research the blood sampling in the rats of control and experimental groups was made for carrying out the work on the definition of the indicators of the general clinical analysis and biochemical structure. All the indicators remained within admissible norms, and standard values, the quantity of leukocytes promoted the increase in the speed of additional weights of experimental animals and the growth of a color indicator within physiological values that could testify to the best saturation of erythrocytes hemoglobin. When carrying out postmortem dissection negative influence of the meat and cereal composition entered into a product on an internal of laboratory animals it was not revealed. All this testifies to the safety of minced meat on the basis of the meat of quail enriched with proteinaceous and carbohydrate composition and enzyme of transglutaminase. The application of the offered minced meat composition will contribute to expanding meat and cereal assortment.

Keywords: minced meat, proteinaceous and carbohydrate composition, laboratory animals, clinical blood test, biological safety.

Введение. Важнейшим условием поддержания здоровья и долголетия человека является его рациональное питание, которое должно включать: баланс энергии, удовлетворение потребностей организма в определенном количестве и соотношении пищевых веществ и режим питания [5]. Получение хорошей качественной готовой продукции определяется двумя основными фракторами: пищевой ценностью и ее безопасностью.

На сегодняшний день пищевая промышленность выпускает огромное количество разного рода продуктов с содержанием в них ферментов и ферментных препаратов, которые, несомненно, при внесении в продукт или сырье вызывают в нем желательные изменения.

В мясной промышленности использование диетических видов мяса, к которым относят мясо индейки, кролика, перепелиное мясо и т. д., в наше время набирает темп.

При проводимых исследованиях комбинированных мясорастительных продуктов разработана фаршевая композиция из мяса перепела и муки из зерна тритикале сорта Укро, произрастающего на территории Амурской области, и введение в фарш фермента трансглютаминазы, который способствует лучшей структуре, улучшению качества продукта. Возникает вопрос, а безопасен ли этот продукт для человека? Любой разработанный новый продукт с добавлением чего-то нового или малоизвестных для людей продуктов вызывает сомнения.

Чтобы убедиться в безопасности разработанных новых продуктов питания на организм человека, проводятся опытные лабораторные исследования и разработки. Для многих видов исследований в пищевой промышленности и медицине целесообразно, быть может, для некоторых защитников животных и негуманно, все научные разработки проводить на лабораторных животных, в качестве которых используют мышей, крыс, кроликов, обезьян, лягушек, перепелов, морских свинок и других животных, что является безопасным и полезным для здоровья человека.

Крысы, как правило, в любых лабораториях являются самыми популярными подопытными видами животных, применяемых для разного рода испытаний и исследований. Их организм часто используют в качестве биологической модели за схожесть генов на $90 \%$ с человеком. У крыс высокая плодовитость, крысы неприхотли- 
вы в содержании и у них относительно короткий срок онтогенеза. Часто крысы конкурируют с мышами, но за их большую физиологическую схожесть с человеком для исследований и опытов выбирают крыс $[4,7]$.

Цель исследования: определить безопасность фарша на основе мяса перепела, обогащенного белково-углеводной композицией и ферментом трансглютаминазой.

Задачи исследования: провести экспериментальное скармливание и исследовать на безопасность фраршевый продукт на основе мяса перепела, обогащенного белково-углеводной композицией и ферментом трансглютаминазой; определить влияние его на организм лабораторных животных, дать описание биохимических, общих клинических показателей крови и патологических изменений в органах белых лабораторных крыс.

Объекты и методы исследований. На основе фаршевой композиции приготовлены опытные образцы [1-3]. Предложенная композиция была апробирована на лабораторных животных, а именно на самцах белых лабораторных крыс.

Для гематологических и биохимических исследований крови забор крови осуществляли из сонной артерии и яремной вены лабораторных крыс. Для гематологического исследования использовали цельную стабилизированную кровь путем внесения в пробирку гепарина из расчета 2-3 капли 1\%-го раствора на 10 мл крови и определяли: количество эритроцитов, количество лейкоцитов, уровень гемоглобина и цветовой показатель. Количество эритроцитов и лейкоцитов определяли при помощи камеры Горяева, уровень гемоглобина - на биохимическом фотометре «StatFax 1904+R» (производитель: Awareness Technology Inc., США) с использованием реактива «Витал» (производитель «Витал Девелопмент», Россия).

Биохимические исследования сыворотки крови выполняли на биохимическом фотометре «StatFax 1904+R» с биохимическими реактивами «Витал» и определяли уровни общего белка, альбумина, глюкозы, общего билирубина, АСТ, АЛТ. Весь цифровой материал, полученный в ходе исследований, был математически обработан при помощи стандартной компьютерной программы Microsoft Excel и проанализирован.

Экспериментальные мероприятия проводились на базе учебного вивария факультета ветеринарной медицины и зоотехнии ФГБОУ ВО «Дальневосточный государственный аграрный университет» (г. Благовещенск). Для эксперимента и проводимых аналогичных работ были ссрормированы три подопытных группы крыс со средней живой массой тела 221,5 $\pm 20,87-$ $267,5 \pm 23,32$ г: контрольная группа, опытная группа 1 и опытная группа 2 (рис. 1).

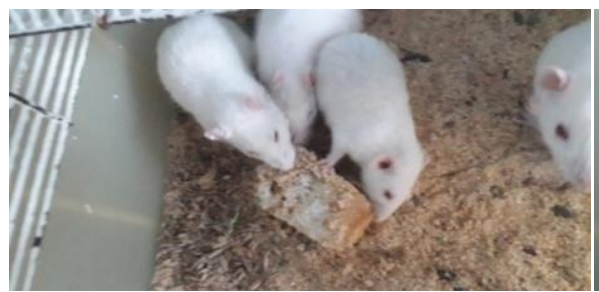

Контрольная группа

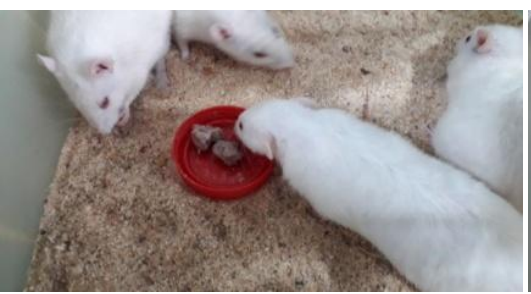

Опытная группа 1

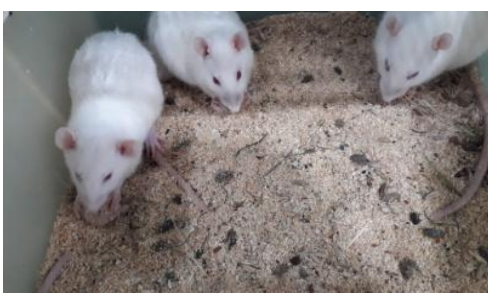

Опытная группа 2

Puс. 1. Кормление крыс

Животным, вошедшим в контрольную группу, применяли схему кормления, разработанную в виварии. В опытной группе 1 крысам к общему рациону дополнительно скармливали фаршевый продукт на основе мяса перепела, обогащенного белково-углеводной композицией и ферментом трансглютаминазой. Животным, вошедшим в опытную группу 2, вводили тот же рацион, что и опытной группе 1, отличающийся другим процентным содержанием фермента в изделиях. Каждодневный доступ к воде не был ограничен для всех групп животных, скармливание проводилось согласно нормативам вивария Дальневосточного ГАУ, кормовые суточные нормы давались в одно и то же время $[4,7]$. Продолжительность опыта составила 35 дней. 
В течение всего периода проводили наблюдение за экспериментальными животными с учетом приема воды, поедания суточной нормы корма и разработанного продукта и их поведения.

В начале и конце всего опытного периода производили взвешивание крыс с использованием весов «Штрих MPII 15-2.5». В конце исследований был произведен забор крови у крыс контрольной и опытных групп для проведения работы по определению показателей общего клинического анализа и биохимического состава.

Результаты исследования и их обсуждение. На протяжении 35 дней опыта наблюдений за экспериментальными белыми крысами было отмечено, что через неделю эксперимента наблюдалась меньшая активность у контрольных крыс в плохую пасмурную и/или дождливую погоду относительно животных из опытных групп 1 и 2. В первую неделю после формирования групп во всех группах наблюдались небольшие драки, особенно при скармливании. Кормление проводилось строго в одно и то же время каждый день, обычный суточный рацион не менял- ся. Практически во всех группах первыми к поеданию корма приступали особи крупнее, а затем все остальные. Опытные группы в первую очередь поедали мясные изделия, а затем приступали к обычному рациону.

Доступ питьевой воды был не ограничен. На протяжении всего опыта велись наблюдения и замеры употребляемой воды. Контрольная группа независимо от погоды, жаркая или дождливая, употребляла на 25-30 \% воды больше, чем опытные группы 1 и 2. При этом животные вели себя активно, обладали хорошим аппетитом, не боясь человека. Шерсть животных в течение всего наблюдения менялась, становилась более блестящей, нос и лапки розовые, глаза чистые.

В первые и последние дни исследований были проведены замеры массы тела у исследуемых крыс (рис. 2). Так, до начала эксперимента вес контрольных крыс превышал вес в опытной группе 1 на $15 \%$, а в опытной группе 2 - на $17 \%$ (табл. 1).

Показатели живой массы тела белых крыс до и после опыта, г

Таблица 1

\begin{tabular}{|c|c|c|c|}
\hline Показатель & Контроль & Опыт 1 & Опыт 2 \\
\hline 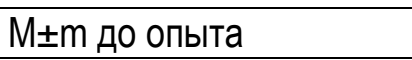 & $267,5 \pm 23,32$ & $226,5 \pm 26,48$ & $221,5 \pm 20,87$ \\
\hline M土m после опыта & $319,2 \pm 9,71$ & $293,5 \pm 16,23$ & $289,5 \pm 18,77$ \\
\hline Абсолютный прирост & 51,7 & 67,0 & 68,0 \\
\hline Относительный прирост & 119 & 130 & 131 \\
\hline
\end{tabular}

Через 30 дней после начала эксперимента были заметны изменения в живой массе тела, во всех экспериментальных группах прирост массы составил: на 51,7 г - в контроле; на 67,0 г в опытной группе 1 и на 68,0 г - в опытной группе 2. Относительный прирост живой массы тела составил в контроле $19 \%$, в опыте 1 - $30 \%$ и в опыте 2 - 31 \% (табл. 2).

Таким образом, применение фраршевой композиции способствовало увеличению скорости прироста живой массы тела у опытных крыс относительно контроля на $11 \%$ (опыт 1) и $12 \%$ (опыт 2), тем самым сократив разрыв в весе между контрольными и опытными животными на 7 и $8 \%$.

Исследование морфологического состава крови белых крыс показал, что во всех группах показатель соответствовал пределам референсных значений, что могло свидетельствовать об отсутствии каких-либо воспалительных процессов в организме опытных животных, что подтверждалось данными клинического осмотра животных. При этом значения были ниже в опытных группах 1 и 2 относительно контрольной на 8 и 26 \% соответственно (табл. 2). 

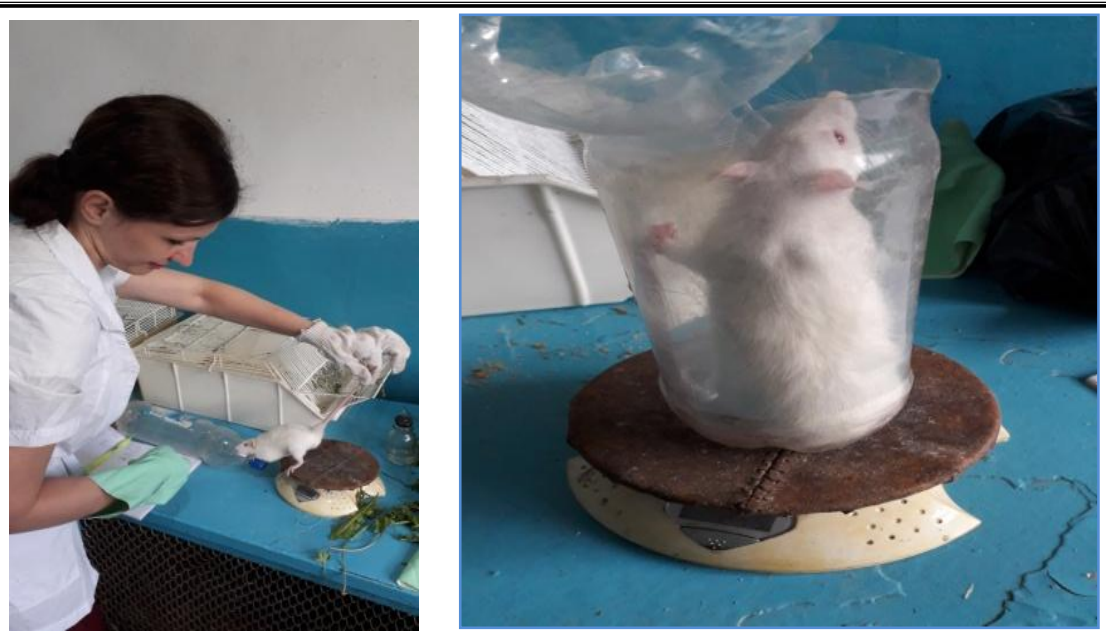

Puc. 2. Взвешивание крыс

Результаты общего клинического анализа крови белых крыс

\begin{tabular}{|l|c|c|c|c|}
\hline \multirow{2}{*}{ Показатель } & \multirow{2}{*}{ Норма } & \multicolumn{3}{|c|}{ Группа животных } \\
\cline { 3 - 5 } & & Контроль & Опыт 1 & Опыт 2 \\
\hline Лейкоциты, $10^{9} / л$ & $5,0-23,0$ & $7,6 \pm 1,42$ & $7,0 \pm 1,59$ & $5,6 \pm 0,91$ \\
\hline Эритроциты, 1012/ л & $7,0-10,0$ & $8,2 \pm 0,92$ & $7,5 \pm 0,59$ & $8,0 \pm 0,41$ \\
\hline Гемоглобин, г/ л & $120-180$ & $121,2 \pm 12,71$ & $121,5 \pm 10,55$ & $123,0 \pm 3,67$ \\
\hline Цветовой показатель & $0,62-0,94$ & $0,72 \pm 0,063$ & $0,82 \pm 0,131$ & $0,77 \pm 0,048$ \\
\hline
\end{tabular}

Крысы в опытной группе 2 отличались от крыс в контроле и опытной группе 1 уровнем относительного содержания гемоглобина крови в одном эритроците. Так, уровень гемоглобина в трех группах находился приблизительно на одном уровне, колебания которого были в пределах 0,2-1,0 \% относительно группы 1 животных. При этом количество эритроцитов в опытных группах было ниже таковых в контрольной группе на 8 и 2 $\%$ соответственно. Значение цветового показателя был наиболее низким у крыс контрольной группы и составлял $0,72 \pm 0,063$, что соответствовало общепринятым показателям. У исследуемых животных опытных групп этот показатель был выше на 14 и 7 \% соответственно [6].
Таким образом, результаты проведенных клинических исследований крови показали, что применение фраршевой композиции, разработанной на базе технологического факультета ФГБОУ ВО «Дальневосточный государственный аграрный университет», не вызывает в организме животных каких-либо воспалительных процессов и способствует некоторому повышению насыщенности эритроцитов гемоглобином, на что указывал цветовой показатель, максимальное значение которого регистрировали у крыс в опытной группе 1.

Результаты изучения биохимического состава сыворотки крови у всех изучаемых белых крыс отражены в таблице 3.

Таблица 3

Биохимические показатели крови белых крыс, $n=4, M \pm m$

\begin{tabular}{|l|c|c|c|c|}
\hline \multirow{2}{*}{ Показатель } & \multirow{2}{*}{ Норма } & \multicolumn{3}{c|}{ Группа животных } \\
\cline { 3 - 5 } & & Контроль & Опыт 1 & Опыт 2 \\
\hline Общий белок, г/л & $56,0-76,0$ & $68,5 \pm 1,22$ & $65,4 \pm 1,08$ & $69,5 \pm 1,85$ \\
\hline Глюкоза, ммоль/л & $8,8-16,3$ & $9,0 \pm 0,32$ & $10,2 \pm 0,53$ & $14,1 \pm 0,80$ \\
\hline Альбумин, г/л & $38,0-48,0$ & $38,5 \pm 1,84$ & $44,3 \pm 1,91$ & $51,2 \pm 4,57$ \\
\hline Общий билирубин, мкмоль/л & $4,0-12,0$ & $6,8 \pm 0,62$ & $7,4 \pm 1,53$ & $9,9 \pm 3,71$ \\
\hline АСТ, Ед/л & $150-300$ & $173,8 \pm 15,36$ & $184,2 \pm 26,30$ & $179,5 \pm 31,21$ \\
\hline АЛТ, Ед/л & $20-92$ & $34,8 \pm 4,70$ & $41,2 \pm 11,53$ & $40,0 \pm 7,58$ \\
\hline
\end{tabular}


Концентрация общего белка в сыворотке крови подопытных животных составляла: в контрольной

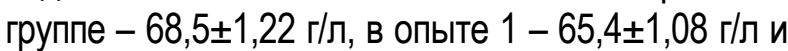
в опыте 2 - 69,5 $\pm 1,85$ г/л, что соответствовало норме, и различия между группами были незначительными (в пределах 1-4 \%) [6].

Все другие показатели также соответствовали фризиологической норме и не превышали общих пределов.

При патолого-анатомическом вскрытии всех подопытных групп крыс патологий внутренних органов не было обнаружено. Половые органы без видимых патолого-анатомических изменений. Кровь соответствовала темно-красному цвету, хорошо сворачивалась. Легкие немного влажные, светло-розового цвета. Печень и почки соответствовали своим размерам и цвету. Сердце также имело свою форму и цвет, без каких-либо отклонений. Вся пищеварительная система не имела никаких видимых патологий [8].

Выводы. Скармливание белым лабораторным крысам на протяжении 35 дней продукта, состоящего из мяса перепела в виде фрикаделек, обогащенного белково-углеводной композицией и ферментом трансглютаминазой в количестве 1 и/или 3 \% не вызвало острых воспалительных процессов в органах пищеварительной системы. На что указывали данные клинического и патологического осмотров. Введение дополнительного продукта в опытных группах способствовало увеличению скорости привесов животных и росту цветового показателя в рамках фризиологических значений, что могло свидетельствовать о лучшем насыщении эритроцитов гемоглобином. При этом следует отметить, что животные, вошедшие в опытные группы, были более активными относительно контрольных крыс.

При вскрытии крыс доказано, что употребление животными мясорастительного продукта из фаршевой композиции с введением фермента в разном процентном соотношении не оказывает негативного влияния на организм животных.

\section{Литература}

1. Гартованная Е.А., Иванова К.С. Производство мясорастительной фаршевой композиции и разработка на ее основе рубленых полуфабрикатов для геродиетического пи- тания // Каталог инновационных разработок в области переработки сельскохозяйственного сырья. - Саратов: Амирит, 2018. - 290 с.

2. Гартованная Е.A., Иванова К.С. Математический анализ и обоснование состава фаршевой композиции // Дальневосточный аграрный вестник. - 2018. - № 3 (47). C. $110-116$.

3. Гартованная Е.А., Иванова К.С. Особенности производства геродиетических мясных фаршевых продуктов на основе нетрадиционного сырья // Инновации в пищевой промышленности: мат-лы 3-й всерос. науч.практ. конф. (г. Благовещенск, 20 февраля 2018 г.). - Благовещенск: Изд-во Дальневосточного ГАУ, 2018. - С. 34-39.

4. Западнюк И.П., Западнюк В.И., Захария Е.A., Западнюк Б.В. Лабораторные животные. Разведение, содержание, использование в эксперименте. - Киев: Вища школа, 1983. - 383 C.

5. Касьянов Г.И., Запорожский А.А., Юдина С.Б. Технология продуктов питания для людей пожилого и преклонного возраста. Ростов на/Д.: МарТ, 2001. - 192 с.

6. Каркищенко Н.Н., Каркищенко В.Н., Семенов X.X. и др. Эффрект пептидов животного происхождения, оцениваемый по чувствительности к гипоксии, некоторым этологическим характеристикам и показателям крови крыс // Биомедицина. - 2013. - № 6. C. 15.

7. Ковалевский К.Л. Лабораторное животноводство. - М., 1958. - 323 c.

8. Кудрявцев А.А., Кудрявцева Л.А. Клиническая гематология животных. - М.: Колос, 1974. - 399 c.

\section{Literatura}

1. Gartovannaya E.A., Ivanova K.S. Proizvodstvo myasorastitel'noj farshevoj kompozicii i razrabotka na ee osnove rublenyh polufabrikatov dlya gerodieticheskogo pitaniya // Katalog innovacionnyh razrabotok v oblasti pererabotki sel'skohozyajstvennogo syr'ya. Saratov: Amirit, 2018. - $290 \mathrm{~s}$.

2. Gartovannaya E.A., Ivanova K.S. Matematicheskij analiz i obosnovanie sostava farshevoj kompozicii // Dal'nevostochnyj 
agrarnyj vestnik. - 2018. - № 3 (47). S. 110-116.

3. Gartovannaya E.A., Ivanova K.S. Osobennosti proizvodstva gerodieticheskih myasnyh farshevyh produktov na osnove netradicionnogo syr'ya // Innovacii v pishchevoj promyshlennosti: mat-ly 3-j vseros. nauch.- prakt. konf. (g. Blagoveshchensk, 20 fevralya 2018 g.). - Blagoveshchensk: Izd-vo Dal'nevostochnogo GAU, 2018. - S. 34-39.

4. Zapadnyuk I.P., Zapadnyuk V.I., Zahariya E.A., Zapadnyuk B.V. Laboratornye zhivotnye. Razvedenie, soderzhanie, ispol'zovanie $\mathrm{V}$ eksperimente. - Kiev: Vishcha shkola, 1983. $383 \mathrm{~s}$.
5. Kas'yanov G.I., Zaporozhskij A.A., Yudina S.B. Tekhnologiya produktov pitaniya dlya lyudej pozhilogo i preklonnogo vozrasta. - Rostov na/D.: MarT, 2001. - $192 \mathrm{~s}$.

6. Karkishchenko N.N., Karkishchenko V.N., Semenov H.H. i dr. Effekt peptidov zhivotnogo proiskhozhdeniya, ocenivaemyj po chuvstvitel'nosti k gipoksii, nekotorym etologicheskim harakteristikam i pokazatelyam krovi krys // Biomedicina. - 2013. - № 6. - S. 15.

7. Kovalevskij K.L. Laboratornoe zhivotnovodstvo. - M., 1958. - $323 \mathrm{~s}$.

8. Kudryavcev A.A., Kudryavceva L.A. Klinicheskaya gematologiya zhivotnyh. - M.: Kolos, 1974. - 399 s. 